Budapest International Research and Critics Institute-Journal (BIRCI-Journal)

Volume I, February 2018, Page: 27-33

e-ISSN: 2615-3076(Online), p-ISSN: 2615-1715(Print)

Www.birci-journal.com

emails; birci.journal@gmail.com andbirci.journal.org@gmail.com

\title{
LANGUAGE STANDARDIZATION IN GENERAL POINT OF VIEW
}

\author{
Ramlan \\ Jabal Ghafur University (UNIGHA), Aceh, Indonesia \\ Email:ramj.kbaju@yahoo.com
}

\begin{abstract}
Language has the great roles in human's lives because it is used as a means of communication among the member of society. Naturally different ethnics of course bave the different race, the tribe, and the language. Language is much more than a system of communication, it is a symbolical marker that distinguishes who belongs to a group and who is outside. Language has been traditionally considered as a central feature of ethnic identity and national identity, therefore, the identity and the integrity of a nation is well-showed by a language. Moreover, standardized language is a way to support a common identity. A language should be standardized to get its formality. The processes of language standardization are: selection, codification, elaboration of function, and acceptance.
\end{abstract}

Keywords: language, standard language, language standardization process

\section{INTRODUCTION}

Language is an arrangement of arbitrary symbols possessing an agreed upon significance within a community; furthermore, these symbols can be used and understood independent of immediate contexts, and they are connected in regular ways. In line with this definition, therefore, it acceptable to state that language has the great roles in human's lives because it is used as a means of communication among the member of the society. Whatever in a certain ethnics something being conveyed to another person can not be done without the language.

Woolard \& Schieffelin (1994) say that language is much more than a system of communication, it is a symbolical marker that distinguishes who belongs to a group and who is outside. Naturally different ethnics of course have a different race, tribe, and language as stated by Bascoboinik (2008) that language, from an anthropological point of view, has been 


\section{Budapest International Research and Critics Institute-Journal (BIRCI-Journal) Volume I, February 2018, Page: 27-33 e-ISSN: 2615-3076(Online), p-ISSN: 2615-1715(Print) Www.birci-journal.com emails; birci.journal@gmail.com andbirci.journal.org@gmail.com}

traditionally considered as a central feature of ethnic identity. This perspective is also applicable to the principle that a language is as the characteristics of a nation or a country. Therefore, the identity and the integrity of a nation is well-showed by a language.

A national language should be standardized to get its formality. A standard language is actually one of the tribal languages, a group of people of the same race, and with the same customs, language, religion, etc., in a certain country, which has been standardized (e.g. Malay has become standardized language of Indonesia)

Standardization is the process in which the language is standardized for its linguistic forms as well as social communicative functions of language. A language becomes standard through a process of standardization. A process generally needs some well-prepared and systematic steps and procedures to reach it.

\section{REVIEW OF LITERATURE}

They are so many languages in the world; and there are so many features in a language. Basically, linguistics is the study of the language. It has four branches:, phonetics (the study of speech sounds and how they are produced), morphology (the study of the forms of words), syntax (the study that words and phrases are put together to form sentences in a language), semantics (the study of meaning in language), and pragmatics (the study of the way in which language is used to express what somebody really means in particular situations, especially when the actual words used may appear to mean something different).

In relation to the formality or standardization point of view, the language is divided into two kinds: standard language and non-standard language. Holmes (2001) defines standard variety is generally one which is written, and which has undergone some degree of regularization or codification (for example, in grammar and dictionary); it is recognized as prestigious variety of code by a community.

The process of making a language become standard is named language standardization. Wardhaugh (2006) defines language standardization as "The process by which a language has been codified in some way. That process usually involves the development of such things as grammars, spelling books, and dictionaries, and possibly a literature”.

This definition has two main features: written language is the representation of a language by means of a writing system; and regularization: to make a certain language that 


\section{Budapest International Research and Critics Institute-Journal (BIRCI-Journal) Volume I, February 2018, Page: 27-33 e-ISSN: 2615-3076(Online), p-ISSN: 2615-1715(Print) Www.birci-journal.com emails; birci.journal@gmail.com andbirci.journal.org@gmail.com}

already exists legal or official. Therefore, Standard language is a particular language, which is correct, acceptable and used by most people. It is much more related to the written language, which involves the features of orthographical: the system of spelling in a language; morphological: the form of words; and syntactical: the way that words and phrases are put together to form sentences in a language.

\subsection{The Advatages and Disadvantages of Language Standardization}

A new thing usually produces an advantage or a disadvantage. The advantage is concerned with the quality of something that makes it better or more useful, whereas the disadvantage deals with something that causes problems and tends to stop somebody or something from succeeding or making progress.

In terms of language standardization, it also affects two different things in which the decider intends to consider them. For instance, Wardhaugh (2000) points out four advantages of language standardization. They are as follows:

1) allows the language to serve as a model for everyone in the community to agree upon in order to communicate;

2) having a common, mutually comprehensible language unifies the members of a community;

3) can be employed to reflect and symbolize some kind of identity and can also be used to give prestige to speakers; and

4) also makes the language easier to teach in schools.

From these points, therefore, it can be stated that the language standardization has four main positive effects towards the speaker of that language: 1) language model, 2) unifier of people, 3) the identity, and 4) practical in teaching. On the other hand, language standardization also has disadvantages:

1) creates a sense of elitism among the speakers of the standard and a feeling of inferiority in those who continue to use the non-standard form;

2) tends to create an inferiority complex among the low status speakers; and

3) also forces parents who wish for their children to be accepted by the dominant group to conform to the standard variety, possibly neglecting the language and culture they were born into. 
Budapest International Research and Critics Institute-Journal (BIRCI-Journal)

Volume I, February 2018, Page: 27-33

e-ISSN: 2615-3076(Online), p-ISSN: 2615-1715(Print)

Www.birci-journal.com

emails; birci.journal@gmail.com andbirci.journal.org@gmail.com

Based on the explanation of disadvantage mentioned above, it can be said that the advantages of language standardization are much concerned with the elitism, inferiority, and neglecting.

\section{DISCUSSION}

\subsection{The Standardizer of Language}

There are so many experts who try to determine the people or institution that is in charge to do the standardization. One of them is Duranti (1997). He says:

"The creation of national states forces standardization. The process of state formation creates the condition for a unified linguistic market where one linguistic variety acquires the status of standard language.”

This point out that national state is responsible to undertake the standardization. The national states refer to the government. Moreover, Bourdieu, a social theorist, claims that a standard language is the result of sociopolitical processes, including bureaucratic institutions such as schools (as cited in Duranti: 1997). The Bourdieu's opinion refers to the schools as the standardizer of a language. In this case schools are associated to the experts of language or linguists.

Based on those different opinions, therefore, the national state or government and the bureaucratic institutions- the experts of language- are in charge to consider some policies concerning with the language standardization. This is probably the term for European countries, however, in Indonesia, Pusat Bahasa 'Language Center' is well-known as the institution executing the standardization.

\subsection{The Elements of Language Standardized}

Standardization is much more concerned with the written language (e.g. lexical, morphological, and syntactical) rather than the spoken language, for instance phonological language features. This is supported by Wardhaugh (2006) who states that standardization is the process by which a language has been codified in some way. That process usually involves the development of such things as grammars, spelling books, and dictionaries, and possibly a literature.

In addition, Holmes (2001) says that standard variety is generally one which is written, and which has undergone some degree of regularization or codification (for example, in grammar and dictionary); it is recognized as prestigious variety of code by a community. 


\section{Budapest International Research and Critics Institute-Journal (BIRCI-Journal) Volume I, February 2018, Page: 27-33 e-ISSN: 2615-3076(Online), p-ISSN: 2615-1715(Print) Www.birci-journal.com emails; birci.journal@gmail.com andbirci.journal.org@gmail.com}

In relation to the two theories mentioned above, therefore, it is acceptable to state some features of language which are standardized:

1) Grammar: The rules in a language for changing the form of words and joining them into sentences;

2) Spelling: The act of forming words correctly from individual letters;

3) Word: A single unit of language which means something and can be spoken or written;

4) Pronunciation: The way in which a language or a particular word or sound is pronounced; and

5) System of writing: The way in which books, kinds of letter, articles, posters, advertisements, announcements, notices, and the other forms of scientific writing are written down.

\subsection{The Process of Language Standardization}

Standardization is a necessary and vital process in any language. Deumert (2004) states that linguistically- oriented approach to language standardization have often concentrated on the identification of the regional and/or social dialects which form the phonological, morphological, and syntactic basis of standard language.

Standardizing a language needs some interrelated steps (Holmes: 2001): selection: choosing the variety or coded to be developed; codification: standardizing its structural or linguistic features; elaboration: extended its functions for use in new domains; and securing its acceptance: enhancing its prestige, for instance, and encourage people to develop pride in the language or loyalty towards it.

\section{Selection}

Variability is a fact of life for almost all languages. There are different regional dialects, class dialects, and situational varieties. Standardization represents an attempt to curtail, minimize if not eliminate this high degree of variability (Stadler: 1983). The easiest solution seems to be to pick (although not arbitrarily) one of these varieties to be elevated to the status of the standard.

One of the existing dialects is chosen for standardization purposes. The chosen dialect is likely to be one spoken be the more powerful and better educated groups living in or near the capital.

\section{Codification}

The norms and rules of grammar, use, etc. which govern the variety selected have to be formulated, and set down definitively in grammars, dictionaries, spellers, manuals of style, texts, 


\section{Budapest International Research and Critics Institute-Journal (BIRCI-Journal) \\ Volume I, February 2018, Page: 27-33 \\ e-ISSN: 2615-3076(Online), p-ISSN: 2615-1715(Print) \\ Www.birci-journal.com \\ emails; birci.journal@gmail.com andbirci.journal.org@gmail.com}

etc. The selected dialect is provided with a written grammar and a dictionary, so that it can be used in official documents, taught in schools and learnt by foreigners (Holmes: 2001).

\section{Elaboration}

For the variety selected to represent the desired norms, it must be able to discharge a whole range of functions that it may be called upon to discharge, including abstract, intellectual functions (Holmes: 2001). Where it lacks resources to do so, these are developed. Thus a standard language is often characterized as possessing 'maximal variation in function, minimal variation in form'. Where necessary, ways of talking and writing about technology and other development need for modern education and commerce will be develop by an academy or language bureau in the first instance it may be necessary to borrow or invent vocabulary lists.

\section{Acceptance}

The 'acceptance' by the community of the norms of the variety selected over those of rival varieties, through the promotion, spread, establishment and enforcement of the norms. This is done through institutions, agencies, authorities such as schools, ministries, the media, cultural establishments, etc. (Holmes: 2001). In fact, the standard language comes to be regarded not just as the best form of the language, but as the language itself (eg consider the claim that Mandarin is Chinese in Singapore). The other varieties are then dialects, which tend implicitly to get stigmatised as lesser forms, associated with the not too highly regarded people, who are seen as less educated, slovenly, uncouth, etc.

\section{CONCLUSION}

Language is much more than a system of communication, it is a symbolical marker that distinguishes who belongs to a group and who is outside. Naturally different ethnics of course have a different race, tribe, and language as stated by Bascoboinik (2008) that language, from an anthropological point of view, has been traditionally considered as a central feature of ethnic identity. It is also in linked to the perspective that

In some countries in the world such as Indonesia, Singapore, Malaysia, Philippine, etc. coding a language to be national and official language is very crucial and has to follow the steps of it: selection: choosing the variety or coded to be developed; codification: standardizing its structural or linguistic features; elaboration: extended its functions for use in new domains; and securing its acceptance: enhancing its prestige, for instance, and encourage people to develop pride in the language or loyalty towards it. 


\section{Budapest International Research and Critics Institute-Journal (BIRCI-Journal) Volume I, February 2018, Page: 27-33 e-ISSN: 2615-3076(Online), p-ISSN: 2615-1715(Print) Www.birci-journal.com emails; birci.journal@gmail.com andbirci.journal.org@gmail.com}

The steps mention previously is very interrelated to each other; therefore, the politicians, linguists, and another social factor should equally take a role to achieve it and recognize it as an individual and mutual responsibility. A country will meet her language change and probably language shift, if one of the things mentioned is not taken into account.

Standardization is much more concerned with the written language (e.g. lexical, morphological, and syntactical) rather than the spoken language, for instance phonological language features.

\section{REFERENCES}

Boscoboinik, Andrea (2008) Standardired Language as a Way to Support a Common Identity: The Case of Roma Communities. Switzerland: University of Fribourg.

Deumert, Ana (2004) Language Standardization and Language Change: The Dynamics of Cape Ducth. England: Edinburgh Gate.

Duranti, A. (1997) Linguistic Anthropology. Cambridge, England: Cambridge University Press.

Holmes, Janet (2001) Learning About language: An Introduction to Sociolinguistics. England: Edinburgh Gate

http://en.wikipedia.org/wiki/Formality, accessed on March 26, 2010

http://en.wikipedia.org/wiki/Written_language, accessed on March 26, 2010

Morris, Charles (1946) Signs, Language and Behavior. Englewood Cliffs, NJ: Prentice-Hall.

Stadler, B. (1983). Language Maintenance and Assimilation: The Case of Selected German Speaking Immigrants in Vancouver, Canada. Canadian Cataloguing in Publications Data.

Wardhaugh, R. (2006) An Introduction to Sociolinguistics. Malden, MA: Blacwell Publishing

Woolard K. A. \& Schieffelin B. B. (1994) Language Ideology: An Annual Review of Anthropology. 23, $55-82$. 